\title{
INTERNASIONALISASI PENDIDIKAN TINGGI ISLAM MELALUI REALISASI THE GLOBAL GOALS BERBASIS MAQASHID SYARIAH
}

\author{
Rosidin \\ UNISLA Lamongan \\ Email: mohammed_rosidin@yahoo.co.id
}

\begin{abstract}
The era of globalization is characterized by a shift in the concept of citizenship. From nation citizenship to global one. The implication is the need to reform Islamic education based on global standardization and Islamic values. The concrete form is the internationalization of Islamic education through the realization of the global goals based on maqashid sharia. The model established is the education that makes maqashid sharia as the core curriculum (model of comprehensive education), open to all parties to obtain or provide educational (emancipatory), ready to compete in the global competition (competitive), to cultivate the attitude of flexibility and open-minded towards each other (inclusive), cooperate with global citizens (collaborative) and is able to bring actual change for the community (transformative).
\end{abstract}

Era globalisasi ditandai pergeseran konsep kewarganegaraan. Dari warga negara menjadi warga dunia (global citizenship). Implikasinya adalah pentingnya reformasi pendidikan Islam yang didasarkan pada standarisasi global namun Islami. Bentuk konkritnya adalah internasionalisasi pendidikan Islam melalui realisasi the global goals berbasis maqashid syariah. Model pendidikan yang diselenggarakan adalah pendidikan yang menjadikan maqashid syariah sebagai kurikulum inti (model pendidikan komprehensif), terbuka bagi semua pihak untuk memperoleh maupun memberikan pendidikan (emansipatif), siap bersaing dalam kompetisi global (kompetitif), membudayakan sikap luwes dan terbuka terhadap sesama (inklusif), mau bekerjasama dengan seluruh warga dunia (kolaboratif) serta mampu menghadirkan perubahan aktual bagi masyarakat (transformatif).

Keywords: the global goals, maqashid syariah, model of intenational Islamic education 


\section{Pendahuluan}

Di malam hari tanggal 13 November 2015, serangkaian serangan teroris yang meliputi penembakan massal, bom bunuh diri dan penyanderaan terjadi di Paris. Dimulai pada pukul 21.20 waktu setempat, ada tiga bom bunuh diri di luar stadion Stade de France disertai penembakan massal dan bom bunuh diri lainnya di empat tempat berbeda yang berlokasi di sentral Paris. Serangan paling mematikan terjadi di Bataclan Theatre yang menewaskan 89 nyawa dari total 129 korban jiwa. Itupun ditambah 433 korban yang harus dirawat di rumah sakit dan 80 di antaranya mengalami luka serius. Ini adalah serangan paling mematikan di Prancis sejak Perang Dunia II dan serangan paling mematikan di Eropa sejak peristiwa pengeboman kereta api di Madrid pada 2004 silam. Islamic State of Iraq and Syiria (ISIS) mengklaim bertanggung-jawab atas serangan tersebut. Bahkan dalam pernyataan resminya, ISIS menyatakan: "We did it and Paris is just the start of a storm" (https://en.wikipedia.org).

Berita di atas menjadi pukulan telak bagi label khaira ummah yang didengung-dengungkan umat muslim. Fathi Osman berpandangan bahwa predikat sebagai sebaik-baik umat (khaira ummah) sejatinya termanifestasikan dalam tiga hal; pertama, umat muslim dapat hidup berdampingan dengan umat lain yang berbeda dengan dirinya, bukan hidup terpisah dan menutup diri dari kehidupan global yang menjadi keniscayaan; kedua, persatuan kaum muslimin dan solidaritas Islam tidak boleh mengarah kepada tindakan etnosentris atau eksploitasi materi maupun tindakan agresi, sebaliknya umat muslim harus kooperatif dalam menjaga perdamaian, serta mengedepankan moralitas; ketiga, umat muslim seharusnya mau mendengar dan belajar dari pengalaman orang lain dan kemudian mengambil hal-hal yang baik (Muammar, 2013: 245-246).

Tiga hal yang diutarakan Fathi Osman di atas merupakan kebutuhan yang mendesak bagi umat muslim dalam mengarungi kehidupan di era globalisasi. Era globalisasi sendiri ditandai oleh pergeseran konsep kewarganegaraan, yaitu dari warga negara, menjadi warga dunia (global citizenship). Sebagai warga dunia, umat muslim dituntut siap berkompetisi sekaligus berkolaborasi dengan umat lainnya. Akan tetapi, aksi terorisme ISIS di Paris seolah mengindikasikan ketidak siapan umat muslim untuk berkompetisi, apalagi berkolaborasi dengan umat lain. Oleh sebab itu, dibutuhkan fresh ijtihad (meminjam istilah Abdullah Saeed) yang berfungsi sebagai problem solving bagi problematika-problematika kontemporer yang dihadapi umat muslim. 
M. Hashim Kamali menegaskan bahwa dalam menyelesaikan masalah kontemporer, kembali pada makna harfiah teks (al Quran dan al Hadits) adalah sesuatu yang tidak mungkin menyelesaikan masalah (problem solving), bahkan bisa menjadi masalah tersendiri (part of problem), yakni teralienasinya ajaran Islam dalam dinamika kehidupan. Satu-satunya solusi yang tepat adalah menangkap prinsip-prinsip dasar, makna-makna universal, dan tujuan-tujuan yang terkandung di dalamnya untuk kemudian diterapkan dalam wajah baru yang sesuai dengan semangat merealisasikan kemaslahatan umum. Inilah yang dinamakan maqashid based ijtihad (Muammar, 2013: 387).

Ijtihad berbasis maqashid bersifat luwes-dinamis, karena dapat menampung berbagai perkembangan terkini, asalkan mampu mengantarkan pada kemaslahatan alam semesta (rahmatan li al alamin). Atas dasar itu, penulis sepakat dengan Jasser Auda yang menyarankan agar menjadikan United Nations Development Program (UNDP) sebagai standar ilmiah dalam menentukan realisasi maqashid syariah masa kini. Hal ini dikarenakan UNDP tersebut disusun berdasarkan lebih dari 200 indikator, termasuk mengukur partisipasi politik, kemampuan baca-tulis (literasi), keikutsertaan dalam pendidikan, harapan hidup, akses mendapatkan air bersih, ketenagakerjaan, standar hidup dan kesetaraan gender (Auda, 2015: 15).

Hemat penulis, ijtihad berbasis maqashid syariah menjadi tanggung jawab pendidikan tinggi Islam. Hal ini dikarenakan pendidikan tinggi Islam dipenuhi aktivitas-aktivitas akademik yang terkategorikan sebagai ijtihad dan didukung tenaga ahli yang relatif berkompeten sebagai 'mujtahid' masa kini, di samping peran utama pendidikan tinggi Islam untuk mempersiapkan generasi muslim yang memiliki sumber daya manusia unggul yang layak menyandang status 'mujtahid' di masa depan. Di antara karakteristik 'tenaga ahli' di perguruan tinggi adalah; a). karena literatur yang dikuasainya, ia mampu menyampaikan pendapatnya relatif lebih teratur daripada orang atau lembaga lain; b). karena sifat dan sistematika ilmu yang dikuasainya, ia lebih mungkin bersikap obyektif dan dapat menerapkan nilai-nilai obyektivitas ilmu; c). karena dedikasinya kepada ilmu yang sering mengandung alternatif dan kemungkinan, maka seorang ahli ilmu pengetahuan atau lembaga ilmiah sukar untuk dapat menerima sikap yang bersifat dogmatis atau otoriter; d). di dalam menjawab berbagai masalah yang dihadapinya, ia memiliki gaya yang lebih meyakinkan daripada yang lain (Feisal, 1995: 143).

Pendidikan tinggi Islam (Islamic higher education) telah dan akan terusmenerus memainkan peran esensial dalam pengembangan SDM. Di berbagai 
belahan dunia, institusi-institusi pendidikan tinggi Islam telah menghasilkan tenaga kerja, melakukan terobosan riset, menghasilkan inovasi dan berkontribusi pada pengembangan masyarakat. Sepanjang sejarah, berbagai struktur pendidikan tinggi Islam telah muncul sebagai respon atas berbagai perkembangan sosial, teknologi dan gaya hidup manusia (Rahman, 2012: ix-xi).

Pandangan tersebut dikokohkan oleh Fethullah Gulen yang meyakini bahwa pendidikan merupakan cara terbaik untuk merangkul seluruh kehidupan dan berperan paling signifikan dalam menyebarkan keselarasan, keseimbangan, disiplin dan tatanan dalam kehidupan individu dan sosial. Gulen juga meyakini bahwa jalan menuju keadilan untuk semua (manusia) tergantung pada ketersediaan pendidikan universal yang cukup dan tepat (Muammar, 2013: 517-519).

Implikasi uraian di atas, bagi pendidikan tinggi Islam adalah pentingnya penyelenggaraan pendidikan Islam yang unggul berkaliber internasional (worldclass university). Menurut Muhaimin, karakteristik lembaga pendidikan Islam yang unggul antara lain; pertama, dari aspek Output: a). Prestasi Akademik ditunjukkan dengan NUN (atau IPK), lomba karya ilmiah, lomba mata pelajaran, cara-cara berpikir; b). Prestasi non akademik ditunjukkan dengan keingintahuan yang tinggi, kerjasama yang baik, rasa kasih sayang yang tinggi terhadap sesama, toleransi, kedisiplinan, kerajinan, prestasi olahraga dan kesenian, kepramukaan, dan lain-lain; kedua, dari aspek Proses: a). Proses belajar pembelajaran efektif; b). kepemimpinan kepala lembaga pendidikan yang kuat; c). lingkungan lembaga pendidikan yang aman dan tertib; d) Pengelolaan tenaga kependidikan yang efektif; e). Memiliki budaya mutu; f). memiliki team work kompak, cerdas, dinamis; g). Memiliki kemandirian; h). Adanya partisipasi yang tinggi dari masyarakat; i). Mempunyai keterbukaan; j). Mempunyai kemauan untuk berubah baik secara psikologis maupun fisik; k). Melakukan evaluasi dan perbaikan secara berkelanjutan; 1). Responsif dan antisipatif terhadap kebutuhan; m). Mempunyai komunikasi yang baik; n). Mempunyai akuntabilitas; o). Memiliki dan menjaga sustainabilitas dalam program dan pendanaan; ketiga, dari aspek Input: a). Memiliki kebijakan, tujuan, dan sasaran mutu yang jelas; b). Adanya sumber daya yang tersedia dan siap; c). Staf yang kompeten dan berdedikasi tinggi; d). Memiliki harapan prestasi yang tinggi; e). Fokus pada pelanggan (khususnya peserta didik); f). Adanya input manajemen, yang ditandai tugas yang jelas, rencana rinci dan sistematis, program yang mendukung pelaksanaan rencana dan sistem pengendali mutu yang efektif (Muhaimin, 2011: 104-105). 
Sejalan dengan itu, harus dilakukan upaya reformasi pendidikan tinggi Islam yang mengacu pada standarisasi internasional, namun tetap memperhatikan nilai-nilai Islam. Atas dasar itu, paper ini mengajukan gagasan agar menjadikan The Global Goals dan maqashid syariah kontemporer sebagai acuan standarisasi internasional sekaligus Islami bagi reformasi pendidikan tinggi Islam.

The Global Goals merupakan hasil kesepakatan 193 pemimpin dunia pada 25 September 2015, tentang 17 Sasaran Global (The Global Goals) yang diharapkan dapat tercapai pada tahun 2030, yaitu (www.globalgoals.org dan satu-indonesia.com):

1. Tanpa kemiskinan (no poverty): hilangkan kemiskinan dalam bentuk apa pun di seluruh penjuru dunia;

2. Tanpa kelaparan (zero hunger): hilangkan kelaparan, mencapai ketahanan pangan, perbaikan nutrisi, serta mendorong budidaya pertanian yang berkelanjutan;

3. Kesehatan yang baik dan kesejahteraan (good health and well-being): menjamin kehidupan yang sehat serta mendorong kesejahteraan hidup untuk seluruh masyarakat di segala umur;

4. Pendidikan berkualitas (quality education): menjamin pemerataan pendidikan yang berkualitas serta meningkatkan kesempatan belajar untuk semua orang;

5. Kesetaraan gender (gender equality): mencapai kesetaraan gender dan memberdayakan kaum ibu dan perempuan;

6. Air bersih dan sanitasi (clean water and sanitation): menjamin ketersediaan air bersih dan sanitasi yang berkelanjutan untuk semua orang;

7. Energi bersih dan terjangkau (affordable and clean energy): menjamin akses terhadap sumber energi yang terjangkau, terpercaya, berkelanjutan dan modern untuk semua orang;

8. Pekerjaan yang layak dan pertumbuhan ekonomi (decent work and economic growth): mendukung perkembangan ekonomi yang berkelanjutan, lapangan kerja yang produktif serta pekerjaan yang layak untuk semua orang;

9. Industri, inovasi dan infrastruktur (industry, innovation and infrastructure): membangun infra stuktur yang berkualitas mendorong peningkatan industri yang berkelanjutan serta mendorong inovasi;

10. Mengurangi kesenjangan (reduced inequalities): mengurangi ketidaksetaraan baik di dalam sebuah negara maupun diantara negara- 
negara di dunia;

11. Keberlanjutan kota dan komunitas (sustainable cities and communities): membangun kota-kota serta pemukiman yang berkualitas, aman dan berkelanjutan;

12. Konsumsi dan produksi yang bertanggungjawab (responsible consumption and production): menjamin keberlangsungan konsumsi dan pola produksi;

13. aksi terhadap iklim (climate action): bertindak cepat untuk memerangi perubahan iklim dan dampaknya;

14. Kehidupan bawah laut (life below water): melestarikan dan menjaga keberlangsungan laut dan kehidupan sumber daya laut untuk perkembangan yang berkelanjutan;

15. Kehidupan di darat (life on land): melindungi, mengembalikan dan meningkatkan keberlangsungan pemakaian ekosistem darat, mengelola hutan secara berkelanjutan, mengurangi tanah tandus serta tukar guling tanah;

16. Institusi perdamaan dan peradilan yang kuat (peace and justice strong institutions). Meningkatkan perdamaian termasuk masyarakat untuk pembangunan berkelanjutan, menyediakan akses untuk keadilan bagi semua orang termasuk lembaga dan bertangungjawab untuk seluruh kalangan;

17. Kemitraan untuk mencapai tujuan (partnership for the goals): Memperkuat implementasi dan menghidupkan kembali kemitraan global untuk pembangunan yang berkelanjutan.

Agar selaras dengan nilai-nilai Islam, maka The Global Goals terlebih dahulu harus ditelaah dari perspektif Islami, tepatnya maqashid syariah kontemporer. Konsep maqashid syariah kontemporer mengalami pergeseran, dari "penjagaan" dan "perlindungan" menuju "pengembangan" dan "hak-hak asasi”. Pergeseran ini merupakan kontribusi Ibnu Asyur yang membuka pintu bagi para cendekiawan kontemporer untuk mengembangkan teori maqashid dalam pelbagai cara baru. Orientasi pandangan yang baru itu bukanlah konsep perlindungan (hifdz) versi al Ghazali, melainkan konsep "nilai" dan "sistem" versi Ibnu Asyur. Berikut ini penjelasan lebih detailnya (Auda, 2015: 56-60)

Hifdz al Din (perlindungan agama). Dahulu bermakna 'hukuman atas meninggalkan keyakinan yang benar' versi al Amiri. Namun, akhir-akhir ini bergeser menjadi "kebebasan kepercayaan" (freedom of faiths) versi Ibnu 
Asyur atau "kebebasan berkeyakinan" dalam ungkapan kontemporer lain. Para penganjur pandangan ini sering mengutip ayat al Quran: tiada paksaan dalam agama" sebagai prinsip fundamental, dibandingkan memahaminya sebagaimana pandangan populer dan tidak akurat, yaitu menyerukan "hukuman bagi kemurtadan" (hadd al riddah);

Hifdz al Nafs (perlindungan jiwa raga) dan Hifdz al Irdh (perlindungan kehormatan). Semula berkisar pada penjagaan jiwa raga dan harga diri, namun akhir-akhir ini berangsur-angsur diganti oleh "perlindungan harkat dan martabat manusia", bahkan "perlindungan hak-hak asasi manusia".

Hifdz al Aql (perlindungan akal). Jika selama ini masih terbatas pada larangan minum-minuman keras, sekarang berkembang menjadi 'pengembangan pikiran ilmiah', 'perjalanan menuntut ilmu', 'melawan mentalitas taklid', dan 'mencegah mengalirnya tenaga ahli ke luar negeri';

Hifdzh al Nasb (perlindungan keturunan). Pada abad ke-20 M para penulis maqashid secara signifikan mengembangkan 'perlindungan keturunan' menjadi teori berorientasi keluarga, misalnya 'peduli keluarga';

Hifdz al Mal (perlindungan harta). Jika semula bermakna 'hukuman bagi pencurian' versi al Amiri dan 'proteksi uang' versi al Juwaini, akhir-akhir ini berkembang menjadi istilah-istilah sosio-ekonomi yang familier, misalnya 'bantuan sosial', 'pengembangan ekonomi', 'distribusi uang', 'masyarakat sejahtera' dan 'pengurangan perbedaan antar-kelas sosial-ekonomi'. Pengembangan ini memungkinkan penggunaan maqashid untuk mendorong pengembangan ekonomi, yang sangat dibutuhkan di kebanyakan negara-negara berpenduduk mayoritas muslim.

\section{Telaah The Global Goals dari Perspektif Maqashid Syariah}

Poin The Global Goals yang selaras dengan Perlindungan Agama adalah Institusi Perdamaian dan Peradilan yang Kuat. Artinya, perlindungan agama pada era globalisasi diarahkan pada terwujudnya perilaku religius yang mencerminkan kedamaian dan keadilan. Hal ini selaras kandungan Surat al Nahl: 90 serta Hadits riwayat Abu Musa al Asy'ari RA:

Para sahabat bertanya: "Wahai Rasulullah, Islam yang bagaimanakah yang lebih utama?". Rasulullah SAW bersabda: "Muslim yang membuat orang lain selamat dari (keburukan) lisan (perkataan) dan tangan (perbuatan)nya"(HR. al Bukhari).

Ringkasnya, seorang muslim dituntut untuk berkontribusi positif kepada orang lain melalui perkataan dan perbuatan, semisal membantu penyelenggaraan pendidikan Islam sesuai kompetensinya. Jika belum mampu, 
minimal perkataan dan perbuatannya tidak menimbulkan dampak negatif bagi orang lain, semisal tidak mendakwahkan ajaran-ajaran Islam yang memicu tindak anarkis-teroris dengan label jihad islami.

Perlindungan jiwa raga diarahkan pada realisasi kesehatan yang baik dan kesejahteraan. Kesehatan yang baik terkait dengan kesehatan fisik, sedangkan kesejahteraan terkait dengan kesehatan psikis. Dalam Islam, kesehatan harus difungsikan semaksimal mungkin untuk aktivitas-aktivitas yang produktif dan bermanfaat, sebagaimana Hadits riwayat Ibnu Abbas RA:

Rasulullah SAW bersabda: "Optimalkan lima hal sebelum (tiba) lima hal lainnya: Mudamu sebelum tuamu, sehatmu sebelum sakitmu, kayamu sebelum fakirmu, waktu luangmu sebelum waktu sibukmu, dan hidupmu sebelum wafatmu (HR. al Hakim).

Islam kaya akan ajaran nilai-nilai kebaikan, mulai dari khair yang merupakan kebaikan universal seperti kejujuran, keadilan, shalih yang identik dengan aktualisasi keimanan seseorang seperti shalat, sabar, ma'ruf yang mengakomodasi kebaikan menurut nilai-nilai universal ajaran Islam sekaligus nilai-nilai domestik kearifan lokal budaya masyarakat muslim seperti Halal bi Halal, upacara bendera, hingga hasanah yang mencerminkan hal-hal positif secara empiris, rasional maupun psikologis seperti kemakmuran ekonomi, prestasi ilmiah. Nilai-nilai kebaikan itulah yang seharusnya menjadi sasaran seorang muslim dalam mengisi hidupnya.

Perlindungan harga diri menyangkut kesetaraan gender. Tidak ada superioritas kaum laki-laki di atas kaum wanita. Masing-masing memiliki peran gender yang berbeda satu sama lain. Keduanya saling melengkapi sebagaimana tercermin pada penggunaan term zawj (pasangan) yang merepresentasikan lakilaki dan wanita sekaligus, semisal dalam Surat al Najm: 45 dan al Zukhruf: 12. Kesetaraan gender membuka peluang kompetisi maupun kerjasama antara laki-laki dan wanita dalam berbagai aktivitas kehidupan. Misalnya kompetisi antara calon legislatif laki-laki dengan calon legislatif wanita atau kerjasama antara laki-laki dan wanita untuk menjadi pimpinan sebuah institusi atau instansi.

Pendidikan berkualitas menjadi sasaran perlindungan akal dalam konteks masa kini. Wujudnya adalah reformasi pendidikan Islam secara total demi mewujudkan pendidikan yang berkualitas dari segi input, proses maupun output. Surat Ali Imran: 190-191 dan Surat al Mujadilah: 11 merupakan ayat al Quran yang memberikan landasan reformasi pendidikan Islam yang berorientasi pada pembinaan pribadi yang religius dalam ruang privat, namun 
penuh toleransi sekaligus kompetitif dalam ruang publik.

Untuk itu, kurikulum pendidikan Islam seyogyanya mengintegrasikan substansi rumpun ilmu Pendidikan Agama Islam (PAI) dengan rumpun Ilmu Pengetahuan Alam (IPA), Ilmu Pengetahuan Sosial (IPS) dan Ilmu Humaniora, termasuk Pendidikan Kewarganegaraan. Sehingga output pendidikan Islam memiliki kepribadian religius, ikut serta mengolah Sumber Daya Alam, cakap dalam interaksi sosial, serta mendukung visi-misi bangsa dan negara Republik Indonesia.

Perlindungan keluarga pada era globalisasi mengalami pemekaran, karena bukan hanya ditujukan pada perikemanusiaan, melainkan juga perikemakhlukan (meminjam istilah Harun Nasution). Poin global goals yang relevan dengan perikemanusiaan adalah keberlanjutan kota dan komunitas serta kemitraan untuk mencapai tujuan. Sedangkan poin global goals yang relevan dengan perikemakhlukan adalah air bersih dan sanitasi, aksi terhadap iklim, kehidupan bawah laut dan kehidupan di darat. Surat al Hujurat: 9-13 begitu jelas memaparkan pentingnya perikemanusiaan, sedangkan Surat al A'raf: 56 menegaskan pentingnya perikemakhlukan menurut ajaran Islam.

Saat ini tampak nyata pentingnya dari poin-poin global goals di atas. Misalnya menjamin ketersediaan air bersih untuk kebutuhan sehari-hari, perbaikan sanitasi untuk mencegah banjir, aksi reboisasi untuk menjaga iklim agar tidak mengalami global warming, melestarikan aneka hayati yang tinggal di bawah laut maupun di daratan. Semua itu mustahil dilakukan sendiri. Harus ada kerjasama antar berbagai elemen, sehingga dibutuhkan "kemitraan untuk mencapai tujuan". Semua itu dimaksudkan untuk menjamin "keberlanjutan kota dan komunitas".

Tampaknya perlindungan harta menjadi prioritas global goals. Ada enam poin yang selaras dengan perlindungan harta, yaitu: tanpa kemiskinan; tanpa kelaparan; energi bersih dan terjangkau; pekerjaan yang layak dan pertumbuhan ekonomi; industri, inovasi dan infrastruktur; mengurangi kesenjangan; serta konsumsi dan produksi bertanggungjawab. Surat al Baqarah: 267 dan al Hasyr: 7 adalah contoh ayat yang relevan dengan topik ini.

Intinya, kesejahteraan ekonomi dapat tercipta melalui implementasi berbagai faktor. Sasaran utamanya adalah mengentaskan kemiskinan, menanggulangi bahaya kelaparan, atau setidaknya mengurangi jurang kesenjangan antara si kaya dan si miskin. Untuk itu, dibutuhkan pembudayaan konsumsi dan produksi yang bertanggungjawab. Konsumsi dan produksi bukan lagi sekedar aktivitas egois-individual, melainkan sudah menjadi aktivitas sosial yang 
bertanggungjawab. Semisal proses produksi yang ramah lingkungan dan konsumsi yang hemat.

Industri, inovasi dan infrastruktur menjadi perhatian bersama antara pihak pemerintah maupun swasta, sehingga mampu menyediakan lapangan pekerjaan yang layak demi pertumbuhan ekonomi secara nasional. Pada saat itulah, ada peluang besar terwujudnya energi bersih dan terjangkau bagi masyarakat. Berikut formulasi The Global Goals dari perspektif maqashid syariah.

Tabel 1. Formulasi The Global Goals dari Perspektif Maqashid Syariah

\begin{tabular}{ccl}
\hline No & \multicolumn{1}{c}{ Maqashid Syariah } & \multicolumn{1}{c}{ The Global Goals } \\
\hline 1 & Perlindungan Agama & $\begin{array}{l}\text { (16) Institusi Peradilan yang Kuat dan } \\
\text { Kedamaian }\end{array}$ \\
\hline 2 & Perlindungan Jiwa-Raga & $\begin{array}{l}\text { (3) Kesehatan yang Baik dan } \\
\text { Kesejahteraan }\end{array}$ \\
\hline 3 & Perlindungan Harga Diri & (5) Kesetaraan Gender \\
\hline 4 & Perlindungan Akal & (4) Pendidikan Berkualitas \\
\hline & & $\begin{array}{l}\text { (11) Keberlanjutan Kota dan Komunitas } \\
\text { (17) Kemitraan untuk Mencapai Tujuan; (6) }\end{array}$ \\
& Perlindungan Keluarga & $\begin{array}{l}\text { Air Bersih dan Sanitasi (13) Aksi terhadap } \\
\text { Iklim (14) Kehidupan Bawah Laut (15) }\end{array}$ \\
& & Kehidupan di Darat \\
\hline & & $\begin{array}{l}\text { (1) Tanpa Kemiskinan (2) Tanpa Kelaparan } \\
\text { (7) Energi Bersih dan Terjangkau (8) }\end{array}$ \\
& & $\begin{array}{l}\text { Pekerjaan yang Layak dan Pertumbuhan } \\
\text { Ekonomi (9) Industri, Inovasi dan } \\
\text { Infrastruktur(10) Mengurangi Kesenjangan }\end{array}$ \\
& Perlindungan Harta & 12) Konsumsi dan Produksi Bertanggung \\
& & Jawab
\end{tabular}

\section{Telaah The Global Goals Berbasis Maqashid Syariah dalam Konteks Pendidikan Islam}

Kesehatan yang baik dan kesejahteraan merupakan modal utama manusia. Kesehatan fisik dan psikis merupakan motor yang menggerakkan manusia untuk melakukan berbagai aktivitas produktif, termasuk mengikuti pendidikan. Sehat fisik membuat seseorang mampu beraktivitas, sedangkan sehat psikis, semisal memiliki motivasi atau etos kerja, mempercepat laju aktivitas seseorang. 
Akses pendidikan harus dibuka lebar tanpa ada diskriminasi. Oleh sebab itu, kesetaraan gender harus ditegakkan karena berfungsi mengembalikan harga diri manusia pada posisi setara. Artinya, baik laki-laki maupun wanita sama-sama berhak mendapatkan perlakuan yang adil dalam berbagai dimensi kehidupan, termasuk peluang memperoleh akses pendidikan. Artinya, baik laki-laki maupun wanita, memiliki kesempatan yang sama untuk menjadi peserta didik, pendidik bahkan pengelola lembaga pendidikan.

Pendidikan harus diselenggarakan dengan sungguh-sungguh, sehingga berhak menyandang status pendidikan berkualitas. Pada saat ini, pendidikan yang berkualitas diorientasikan pada realisasi empat kompetensi utama yang harus dimiliki peserta didik abad 21, sebagaimana kesepakatan para pakar pendidikan dunia, yaitu: komunikasi (Communication), kolaborasi (Collaboration), penalaran kritis (Critical Thinking) dan kreativitas (Creativity) yang kemudian lebih akrab dengan akronim Four Cs (4C). Komunikasi dibutuhkan dalam interaksi sosial, terutama dalam era informasi yang multibahasa seperti sekarang ini; interaksi sosial diarahkan pada terciptanya kolaborasi untuk mencapai tujuan bersama, semisal kerjasama short course; penalaran kritis menghadirkan pandangan alternatif (second opinion), semisal berdirinya sekolah rakyat Qaryah Thayyibah di Salatiga atau pesantren rakyat di Malang; sedangkan kreativitas menghasilkan berbagai produk inovatif, semisal media pembelajaran berbasis e-learning dan aplikasi android.

Pendidikan Berkualitas bukan hanya mendidik pribadi yang religius, melainkan juga penuh toleransi terhadap sesama manusia. Dengan kata lain, berjiwa religius dalam ruang privat dan berjiwa toleran dalam ruang publik. Hasil akhirnya adalah generasi muslim yang melestarikan perdamaian dan keadilan (peace and justice strong institutions) di seluruh penjuru dunia sebagaimana prinsip Islam Rahmatan lil Alamin (Islam yang ramah bagi semesta alam). Jadi, kesalehan pribadi, semisal taat ibadah mahdhah, berpadu dengan kesalehan sosial, semisal memiliki kepekaan sosial, bahkan kesalehan universal, semisal peduli lingkungan atau alam.

Perpaduan jiwa yang religius dan toleran dengan empat kompetensi utama (4C) tersebut diimplementasikan untuk pengembangan kualitas SDM dan SDA. Pengembangan SDM dilakukan secara kolaboratif melalui kemitraan untuk mencapai maksud dan ditujukan pada terciptanya keberlanjutan kota dan komunitas. Adapun pengembangan SDA ditujukan pada realisasi air bersih dan sanitasi, peduli kelestarian iklim global (Climate Action), kehidupan di laut (Life Below Water) dan di darat (Life on Land). Dengan demikian, kurikulum 
pendidikan didesain pada pembinaan kualitas kognitif, terutama keterampilan berpikir kritis dan kreatif; pembinaan kualitas afektif, terutama keterampilan berkomunikasi dan bekerjasama dengan orang lain; serta kualitas psikomotorik dalam bentuk aksi-aksi nyata dalam kehidupan sehari-hari, semisal menggunakan produk-produk yang ramah lingkungan, mengampanyekan gerakan peduli kehidupan di laut, ikut serta dalam reboisasi untuk kelestarian kehidupan di darat, dan sebagainya.

Pengembangan SDM dan SDA dilanjutkan pada realisasi kesejahteraan sosio-ekonomi dengan mengedepankan prinsip konsumsi dan produksi yang bertanggungjawab. Hal ini dapat diawali dengan mendidikkan sikap hemat dan menjauhi sikap mubadzir (berlebihan secara kualitatif, semisal membeli barang yang tidak dibutuhkan) maupun israf (berlebihan secara kuantitatif, semisal membeli barang melebihi kebutuhan). Kemudian dilanjutkan dengan memperoleh pekerjaan yang layak, sehingga tercipta pertumbuhan ekonomi. Untuk itu, pendidikan juga bertanggungjawab membekali keterampilan vokasional maupun wirausaha kepada peserta didik, sehingga berpotensi memperoleh pekerjaan yang layak.

Agar pertumbuhan ekonomi melaju lebih pesat lagi, maka harus didukung oleh keberadaan industri, inovasi dan infrastruktur yang representatif. Dalam hal ini, dibutuhkan kerjasama yang solid antara pihak pemerintah dengan swasta. Industri diharapkan mampu menghasilkan produk-produk inovatif, seperti energi yang terjangkau sekaligus ramah lingkungan (Affordable and Clean Energy). Teknologi berbasis tenaga surya adalah salah satu contohnya. Apabila perekonomian mencapai kondisi ideal seperti di atas, maka berpotensi besar untuk mengurangi kesenjangan antara kaya dan miskin (Reduced Inequalities) sehingga akhirnya mampu menciptakan masyarakat yang bebas dari kelaparan (Zero Hunger) bahkan bebas dari kemiskinan (No Poverty).

Berikut ini ilustrasi grafis dari formulasi The Global Goal dari perspektif maqashid syariah dalam konteks reformasi Pendidikan Tinggi Islam: 


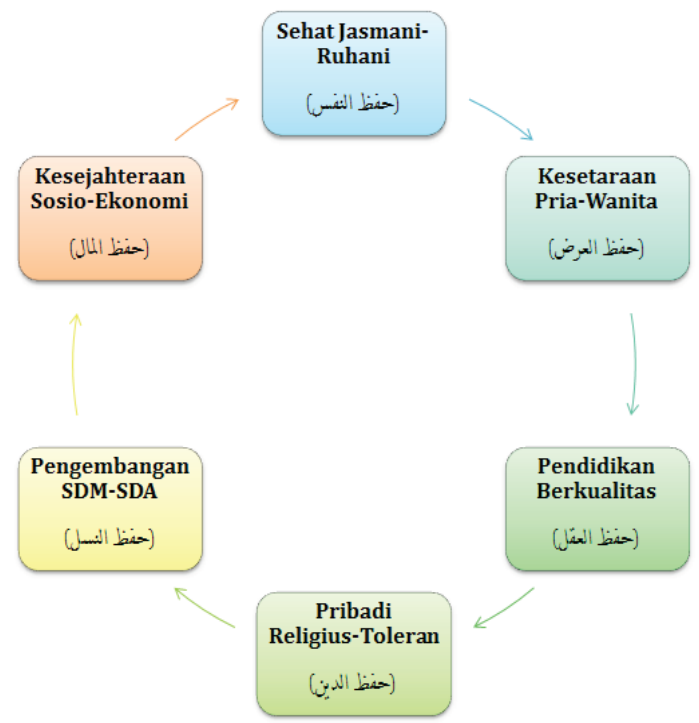

Gambar 1. Formulasi The Global Goal dari Perspektif Maqashid Syariah dalam Konteks Reformasi Pendidikan Tinggi Islam

\section{Internasionalisasi Pendidikan Tinggi Islam}

Berdasarkan analisis terhadap gambar 1, maka internasionalisasi Pendidikan Tinggi Islam melalui realisasi The Global Goals berbasis maqashid syariah diorientasikan pada terciptanya enam model pendidikan: Pendidikan Komprehensif, Pendidikan Emansipatif, Pendidikan Kompetitif, Pendidikan Inklusif, Pendidikan Kolaboratif dan Pendidikan Transformatif.

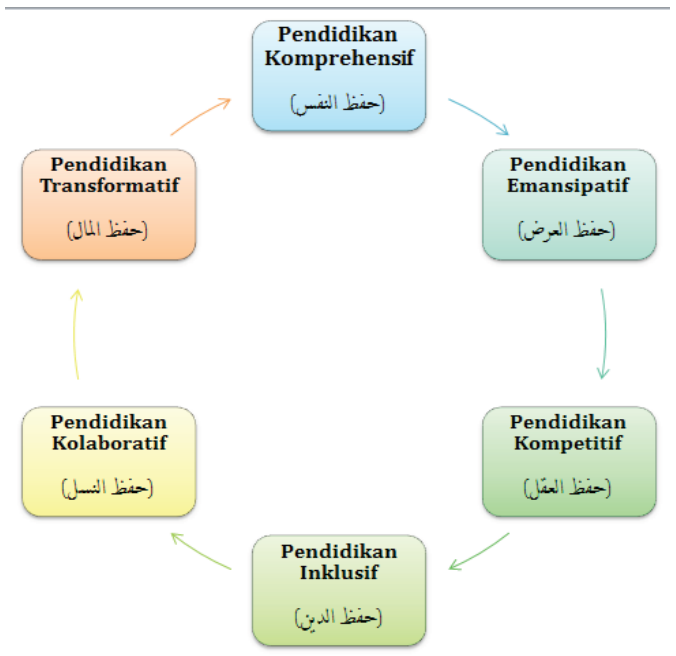

Gambar 2. Model Pendidikan Tinggi Islam Berkaliber Internasional 
Berikut penjelasan lebih detail terkait keenam model pendidikan tersebut:

\section{Pendidikan Komprehensif}

Pendidikan komprehensif adalah pendidikan manusia seutuhnya, yaitu mendidik dimensi fisik dan psikis. Pendidikan komprehensif setidak-tidaknya

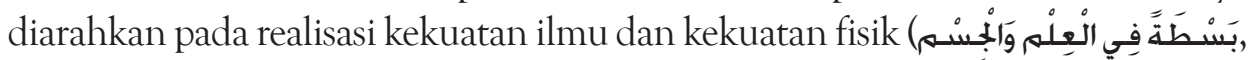
QS al Baqarah: 247). Fisik bertugas untuk bergerak dan beraktivitas, namun selalu membutuhkan akal yang dibekali ilmu pengetahuan sebagai panduan aktivitas. Jika kekuatan fisik merepresentasikan hifdz al nafs dan kekuatan ilmu merepresentasikan hifdz al 'aql, maka idealnya pendidikan komprehensif tidak hanya diarahkan pada dua maqashid syariah itu saja, melainkan harus diarahkan pada realisasi seluruh maqashid syariah. Sehingga pendidikan apapun yang selaras dengan maqashid syariah, tergolong mashlahah, sedangkan pendidikan apapun yang menafikan, apalagi bertolak belakang dengan maqashid syariah, berarti mafsadat (Ali, 2002: 315-316).

Pada titik ini, terbuka 'konsep baru' dalam kurikulum pendidikan tinggi Islam. Kurikulum pendidikan tidak lagi hanya menyangkut domain kognitif, afektif dan psikomotorik, melainkan perlu ditambahkan dimensi maqashid syariah, baik pada aspek tujuan, materi, metode maupun evaluasi pendidikan. Berikut contoh aplikasinya dalam konteks evaluasi pendidikan:

Tabel 2. Evaluasi Pendidikan Islam Berbasis Maqashid Syariah

\begin{tabular}{|c|c|c|}
\hline No & Maqashid Syariah & Garis-garis Besar Penilaian \\
\hline 1 & Perlindungan Agama & $\begin{array}{l}\text { Komponen ibadah fardhu } \\
\text { Komponen ibadah sunah } \\
\text { Komponen perilaku makruh } \\
\text { Komponen perilaku haram }\end{array}$ \\
\hline 2 & Perlindungan Jiwa Raga & $\begin{array}{l}\text { Kesehatan panca indera } \\
\text { Kesehatan anggota tubuh lain } \\
\text { Komponen akhlak terpuji } \\
\text { Komponen akhlak tercela }\end{array}$ \\
\hline 3 & Perlindungan Harga Diri & $\begin{array}{l}\text { Prestasi Akademik } \\
\text { Prestasi Non-akademik }\end{array}$ \\
\hline 4 & Perlindungan Akal & $\begin{array}{l}\text { Kemampuan berpikir kritis } \\
\text { Kemampuan berpikir kreatif }\end{array}$ \\
\hline
\end{tabular}




\begin{tabular}{lll}
\hline 5 & Perlindungan Keluarga & $\begin{array}{l}\text { Keterampilan komunikasi } \\
\text { Keterampilan kolaborasi } \\
\text { Keterampilan kompetisi }\end{array}$ \\
\hline 6 & \multirow{2}{*}{ Perlindungan Harta } & $\begin{array}{l}\text { Keterampilan vokasional } \\
\text { Keterampilan wiraswasta }\end{array}$ \\
\hline
\end{tabular}

\section{Pendidikan Emansipatif}

Pendidikan emansipatif adalah pendidikan yang memberi peluang sama besar bagi semua orang untuk mengembangkan diri. Pendidikan emansipatif di sini selaras dengan konsep keadilan dalam Islam yang menuntut adanya kesempatan yang sama dan seimbang bagi semua orang untuk berkembang dan mengembangkan keseluruhan potensi kebaikan yang dimiliki secara benar, serta adanya perlindungan terhadap pihak-pihak yang lemah dari ekses-ekses negatif pihak yang kuat serta adanya perlakuan yang proporsional. Dalam bidang sosial, keadilan ditegakkan di atas prinsip keseimbangan antara kepentingan pribadi dan masyarakat, kewajiban sosial dan hak individu, laki-laki dan wanita, anak-anak dan orang dewasa, ibadah sosial dan ibadah ritual. Sedangkan keadilan dalam bidang pendidikan didasarkan pada keseimbangan antara kepentingan kelas elit dan kelas rendahan (grass roots), pendidik dan peserta didik, tuntutan kerja dan orientasi intelektual, serta antara pengembangan rasio dan penajaman intuisi (Rahardjo, 2006: 324).

Model pendidikan ini berhasil secara gemilang diaktualisasikan dalam Komunitas Belajar Qaryah Thayyibah di Salatiga, Jawa Tengah. Qaryah Thayyibah merupakan praktik pendidikan yang dikelola bersama dalam sebuah lembaga pendidikan, dimana antara warga desa, pemerintah desa, orang tua murid, guru, anak didik, secara rutin dan terus-menerus mengevaluasi, merencanakan dan mengawasi secara bersama-sama. Dalam Qaryah Thayyibah, guru dan siswa adalah tim dan masyarakat desa menjalin persahabatan dengan lembaga sekolah ini. Kesatuan inilah yang akan membongkar citra bahwa sekolah itu dingin tak berjiwa, birokratis, penyeragaman, asing bagi kaum miskin di pedesaan, dan membosankan bagi guru dan siswa. Tidak ada dikotomi miskin dan kaya, guru menakutkan, murid nakal, mata pelajaran momok dan sebagainya (http://www.kbqt.org).

\section{Pendidikan Kompetitif}

Pendidikan kompetitif adalah pendidikan berbagai kompetensi yang dibutuhkan untuk memenangi berbagai kompetisi kehidupan. Pendidikan 
kompetitif ditujukan pada tatanan pendidikan yang membekali dasar-dasar kompetensi global (global competencies) yang mengantarkan para peserta didik menjadi world class atau think and act globally (Hayat dan Yusuf, 2010: 4-5). Dalam konteks ini, sikap yang paling tepat bagi umat muslim adalah berusaha untuk mengambil manfaat berupa hal-hal positif dari globalisasi dan inklusifitasnya, sekaligus berusaha sekuat mungkin untuk menjauhi hal-hal negatifnya. Umat muslim juga harus mengembangkan kualitas SDM (ilmu pengetahuan, kinerja) dan SDA (pertanian, perindustrian) (Qardhawi, 2001: 311).

Oleh sebab itu, Pendidikan Tinggi Islam perlu memanfaatkan rumusan dasar-dasar kompetensi global yang diformulasikan oleh tim Partnership for 21 Century Learning (P 21) dalam buku yang berjudul menarik: Building Your Roadmap to 21st Century Learning Environments: A Planning Tool for Education Leaders. Dalam buku tersebut dinyatakan bahwa pendidikan abad 21 tidak lagi sekadar membekali keterampilan 3R (Reading, Writing, Arithmetic) pada peserta didik. Konsep literasi baru meniscayakan keterampilan 4C (Critical Thinking, Communication, Collaboration, Creativity) yang merupakan produk pertama dari kinerja Framework for 21st Century Learning. Dalam bahasa yang lugas, The Hewlett Foundation's Deeper Learning Initiative menawarkan konsep "Deeper Learning, yaitu pembelajar yang menggunakan pengetahuan dan keterampilannya dengan cara tertentu yang membuat mereka siap untuk menghadapi kehidupan nyata. Mereka menguasai materi utama akademik, seperti membaca, menulis, matematik dan sains, namun mereka juga belajar bagaimana berpikir kritis, berkolaborasi, berkomunikasi efektif, belajar mandiri serta percaya diri. Ini baru dari segi pembelajaran, belum lagi dari segi pengajaran dan pembelajaran profesional, penilaian dan akuntabilitas, kepemimpinan dan budaya, serta infrastruktur (http://www.roadmap21.org).

\section{Pendidikan Inklusif}

Pendidikan inklusif adalah pendidikan yang menginternalisasikan karakter religius secara intrinsik dan sikap inklusif secara ektrinsik. Pendidikan inklusif di sini mencontoh model pendidikan yang digagas Fethullah Gulen, yaitu pendidikan yang didasarkan pada cinta, toleransi dan dialog. Menurut Gulen, orang muslim itu memiliki keimanan mutlak kepada Allah SWT. Dia tetap beriman dan fokus memenuhi tugasnya dalam segala situasi dan kondisi (Sevindi, 2008: 27). Bagi Gulen, cinta adalah kehidupan (love is life). Kadar cinta seseorang terhadap umat manusia (love for humankind) tergantung pada pemahaman terhadap jati diri dan merasakan hubungan dengan Allah 
SWT. Sejalan dengan itu, dia mampu mengapresiasi orang lain (Gulen, 2009: 4-6). Hal ini dikarenakan seorang muslim yang penuh cinta, dapat menerima perbedaan pendapat dan keyakinan orang lain, sebab dia benarbenar menghayati pesan agama bahwa perbedaan pendapat di kalangan umat adalah bentuk kasih sayang. Spirit profetik ini menegaskan bahwa cinta dan kasih sayang adalah sumber toleransi. Sedangkan tindakan intoleran, seperti terorisme dan radikalisme, merupakan akibat hilangnya cinta dan kasih sayang di hati manusia (Muammar, 2013: 480-481). Tanpa adanya cinta dan toleransi, maka kedamaian dan keamanan tidak akan tercipta. Tanpa kedamaian dan keamanan, maka mustahil bagi kita untuk melakukan pelayanan apapun bagi masyarakat atau umat manusia (Gulen, 2009: 50-51).

Oleh sebab itu, model pendidikan Gulen bertujuan menanamkan rasa kewarganegaraan yang bertanggung jawab, kerjasama dan dialog antara individu, kelompok, dan bangsa. Selain itu, bertujuan untuk memerangi tirani dan memperjuangkan keadilan, hak asasi manusia, dan toleransi. Dari sini, pendidikan berfungsi menjadi perangkat yang paling efektif untuk mengatasi teror internasional. Gulen sendiri berpendapat bahwa tujuan akhir model pendidikan yang dia gagas adalah pengembangan masyarakat serta untuk melayani kemanusiaan. "Sekarang kita hidup dalam dunia yang global dan luas, pendidikan adalah cara terbaik untuk melayani kemanusiaan dan membangun dialog dengan peradaban lain" (http://fgulen.com).

\section{Pendidikan Kolaboratif}

Pendidikan kolaboratif adalah pendidikan yang mendidikkan karakter kerjasama dengan pihak lain dalam konteks kebaikan dan ketakwaan. Pentingnya karakter kerjasama (kolaborasi) ini ditegaskan oleh Roger Garaudy, seorang filsuf Prancis yang menyatakan dirinya masuk Islam, bahwa umat muslim segera mengakhiri mentalitas isolatif dan membuka diri untuk kerjasama dengan pihak-pihak lain dari kalangan umat manusia, dalam semangat perlombaan penuh persaudaraan, bahkan dengan mereka yang mengaku atheis sekalipun (Effendy, 1998: 45-46).

Pendidikan kolaboratif di sini diorientasikan pada pengembangan kualitas sumber daya manusia maupun sumber daya alam. Pengembangan kualitas sumber daya manusia dikonsentrasikan pada terciptanya manusia terpelajar dan berbudaya yang dapat mengangkat kehormatan atau martabatnya dalam pergulatan dunia internasional yang semakin kompetitif ini. Kemampuan mengembangkan sumber daya manusia akan menjadi kunci terhadap mutu 
penampilan dan persaingan dalam area internasional. Bentuk konkritnya adalah tenaga-tenaga profesional yang sangat ahli, tenaga kerja intelektual, tenaga kerja yang cerdas dan tenaga kerja efisien. Mereka inilah orang-orang yang potensial membangun berbagai jenis industri, termasuk mengelola sumber daya alam, sehingga mampu mendongkrak kemajuan dan kekayaan sebuah negara melalui rekayasa industri (industrial engineering). Pada akhirnya, membuat negaranya menjadi pemain teknologi sekaligus ekonomi di dunia ini, seperti yang ditorehkan oleh Amerika Serikat, Inggris, Jerman, Prancis dan Jepang (Qomar, 2014: 128-131).

Model pendidikan kolaboratif ini sudah dilakukan oleh berbagai lembaga pendidikan tinggi Islam di Indonesia. Misalnya UIN Maliki Malang yang telah membuka kerjasama internasional dengan beberapa lembaga dan berbagai perguruan tinggi di luar negeri, di antaranya: Malaysia, Thailand, Rusia, Arab Saudi, Sudan, Kairo dan lainya (http://www.kompasiana.com). Fakultas Humaniora UIN Maliki yang bekerjasama dengan Deakin University Australia, National University of Singapore (NUS), Prince of Sonkla University Malaysia dan Universiti Kebangsaan Malaysia (Nasional University of Malaysia) (http:// humaniora.uin-malang.ac.id). Dari identitasnya saja dapat diketahui bahwa UIN Maliki menjalin kerjasama internasional dengan lembaga pendidikan tinggi Islam maupun non-Islam.

\section{Pendidikan Transformatif}

Pendidikan transformatif adalah pendidikan yang berorientasi pada terwujudnya transformasi masyarakat menuju masyarakat ideal. Pendidikan transformatif ini diawali dari perbaikan sektor ekonomi, yaitu realisasi pengurangan kesenjangan, sehingga tercipta pemerataan. Hal ini dikarenakan menurut para ahli sosiologi perubahan, pemerataan adalah faktor yang paling banyak mengurangi prasangka sosial. Sedangkan menurut Nurcholish Madjid, prasangka adalah pangkal keonaran sosial yang paling berbahaya (Effendy, 1998: 21). M. Yusuf Hasyim juga berpendapat bahwa program-program yang mendorong ekonomi yang sama rata adalah salah satu cara mendakwahkan Islam. Dalam skala lebih luas, Abdurrahman Wahid menyatakan pentingnya menerjemahkan dimensi personal agama ke dalam dimensi sosial. Al Quran pun menghubungkan Rukun Iman dan Rukun Islam dengan "rukun masyarakat", yaitu memberi perhatian kepada orang-orang yang lemah dan tidak mampu (Woodward, 1999: 245-251).

Selanjutnya pendidikan transformatif tersebut ditujukan pada upaya 
menghadirkan peradaban Islam alternatif dan ideal. Menurut Mujamil Qomar, gambaran riil peradaban tersebut adalah: a) peradaban yang dipengaruhi bahkan dikendalikan nilai-nilai spiritual, b) peradaban yang berfungsi mengembangkan prestasi dan menjaga martabat manusia, c) peradaban yang berusaha membantu menyelesaikan problem manusia, d) peradaban yang memosisikan manusia sebagai subyek kemajuan, e) peradaban yang berorientasi peningkatan iman dan takwa kepada Allah SWT, f) peradaban yang menentramkan dan mengharmoniskan kehidupan manusia, g) peradaban yang ramah lingkungan, baik lingkungan geografis, lingkungan sosial maupun lingkungan budaya (Qomar, 2014: 208).

Pendidikan transformatif di sini dapat mengadopsi gagasan Pesantren Rakyat yang diasuh Ustadz Abdullah Syam di Sumber Pucung, Kabupaten Malang. Dalam Pesantren Rakyat ini, peserta didiknya adalah warga masyarakat lintas usia dan lintas status yang bertempat tinggal di sekitar pesantren. Materi pendidikan bukan hanya ilmu agama, melainkan juga kehidupan secara luas, misalnya belajar bertani, berdagang, membuat kerajian, kesenian, dan lainlain. Selain itu, tranformasi Pesantren Rakyat bergerak dalam permodalan. Praktisnya, mereka yang memiliki modal diajak membantu atau bekerjasama dengan yang tidak memiliki modal. Hubungan simbiosis mutualistik itu melahirkan gerakan ekonomi di sekitar Pesantren Rakyat. Kerjasama antara pemilik modal dan para pekerja yang sudah tampak hasilnya adalah di bidang pertanian, peternakan, dan juga wisata berupa kolam renang. Konsep Pesantren Rakyat memang terkesan sederhana dari tampilan luarnya, tetapi ternyata mampu dan berhasil menciptakan transformasi masyarakat, baik di bidang keagamaan, pendidikan maupun sosio-ekonomi (http://uin-malang.ac.id).

Dengan demikian, reformasi institusi Pendidikan Tinggi Islam berstandar internasional yang ditawarkan paper ini adalah sebagai berikut:

Tabel 3. Model Reformasi Institusi Pendidikan Tinggi Islam Berstandar Internasional Berbasis the Global Goals dan Maqashid Syariah.

\begin{tabular}{ll}
\hline Model Pendidikan & \multicolumn{1}{c}{ Orientasi Reformasi } \\
\hline Komprehensif & $\begin{array}{l}\text { Menjadikan maqashid syariah sebagai kurikulum } \\
\text { inti Pendidikan Tinggi Islam }\end{array}$ \\
\hline \multirow{2}{*}{ Emansipatif } & $\begin{array}{l}\text { Membuka peluang kepada semua pihak untuk } \\
\text { memperoleh maupun memberikan pendidikan } \\
\text { (education for all) }\end{array}$ \\
\hline
\end{tabular}




\begin{tabular}{ll}
\hline Kompetitif & $\begin{array}{l}\text { Menempatkan standar internasional seperti } \\
\text { rumusan The Global Goals sebagai acuan kompetensi } \\
\text { yang didikkan }\end{array}$ \\
\hline Inklusif & $\begin{array}{l}\text { Membudayakan sikap inklusif terhadap sesama } \\
\text { manusia, melalui aktualisasi cinta, toleransi dan } \\
\text { dialog }\end{array}$ \\
\hline \multirow{2}{*}{ Kolaboratif } & $\begin{array}{l}\text { Menjalin kerjasama dengan seluruh warga dunia } \\
\text { (global citizenship) untuk pengembangan sumber } \\
\text { daya manusia dan pemberdayaan sumber daya } \\
\text { alam }\end{array}$ \\
\hline Transformatif & $\begin{array}{l}\text { Menghadirkan transformasiaktual bagi masyarakat, } \\
\text { terutama dalam aspek sosio-ekonomi }\end{array}$ \\
\hline
\end{tabular}

\section{Simpulan}

Era globalisasi ditandai oleh pergeseran konsep kewarganegaraan. Dari warga negara, menjadi warga dunia (global citizenship). Implikasinya adalah pentingnya reformasi pendidikan Islam yang didasarkan pada standarisasi global, namun Islami. Bentuk konkritnya adalah internasionalisasi pendidikan Islam melalui realisasi The Global Goals berbasis maqashid syariah. Model pendidikan yang diselenggarakan adalah pendidikan yang menjadikan maqashid syariah sebagai kurikulum inti (model pendidikan komprehensif), terbuka bagi semua pihak untuk memperoleh maupun memberikan pendidikan (emansipatif), siap bersaing dalam kompetisi global (kompetitif), membudayakan sikap luwes dan terbuka terhadap sesama (inklusif), mau bekerjasama dengan seluruh warga dunia (kolaboratif) serta mampu menghadirkan perubahan aktual bagi masyarakat (transformatif).

\section{Daftar Pustaka}

Ali, Sa'id Isma'il. 2002. Al Sunnah al Nabawiyyah: Ru'yah Tarbawiyyah. Kairo: Dar al Fikr al Araby.

Auda, Jasser. 2015. Membumikan Hukum Islam melalui Maqasid Syariah: Pendekatan Sistem. Terjemahan Rosidin dan Ali Moen'im. Bandung: Mizan.

Effendy, A. Edy, (ed.). 1998. Dekonstruksi Islam Mazhab Ciputat. Jakarta: Zaman.

Feisal, Jusuf Amir. 1995. Reorientasi Pendidikan Islam. Jakarta: Gema Insani Press. 
Gulen, M. Fethullah. 2009. Toward a Global Civilization of Love and Tolerance. New Jersey: Tughra Books.

Hayat, Bahrul dan Yusuf, Suhendra. 2010. Benchmark Internasional Mutu Pendidikan. Jakarta: Bumi Aksara.

Muammar, M. Arfan, dkk. 2013. Studi Islam: Perspektif Insider/Outsider. Jogjakarta: IRCiSoD.

Muhaimin. 2011. Pemikiran dan Aktualisasi Pengembangan Pendidikan Islam. Jakarta: Rajawali Pers.

Qardhawi, Yusuf. 2001. Umat Islam Menyongsong Abad ke-21. Terjemahan oleh Tim Penerjemah Era Intermedia. Solo: Era Intermedia.

Qomar, Mujammil. 2014. Menggagas Pendidikan Islam. Bandung: Remaja Rosdakarya.

Rahardjo, Mudjia (ed.). 2006. Quo Vadis Pendidikan Islam: Pembacaan Realitas Pendidikan Islam, Sosial dan Keagamaan. Malang: UIN Malang Press.

Rahman, Shukran Abd. (ed.). 2012. Diversity of Higher Education Models. Selangor: IIUM Press dan IPPTN.

Sevindi, Newval. 2008. Contemporary Islamic Conversations: M. Fethullah Gulen on Turkey, Islam and the West. New York: State University of New York Press.

Woodward, Mark R. (ed.). 1999. Jalan Baru Islam: Memetakan Paradigma Mutakhir Islam Indonesia. Terjemahan oleh Ihsan Ali Fauzi. Bandung: Mizan.

Sumber Internet

https://en.wikipedia.org/wiki/November_2015_Paris_attacks

http://www.globalgoals.org/

http://satu-indonesia.com/globalgoals/

http://www.roadmap21.org/assets/Creating-Your-Roadmap-to-21st-CenturyLearning-Environments1.pdf

http://www.kbqt.org/p/profile_15.html 
http://fgulen.com/id/portal-berita/kolom-opini/36745-kinerja-hizmet-di-sektorpendidikan.

http://www.kompasiana.com/solihin/uin-maliki-malang-menuju-world-class-un iversity_552013a1a333119a41b65e69.

http://humaniora.uin-malang.ac.id/kerjasama/internasional.

http://uin-malang.ac.id/r/150801/menjadikan-nu-sebagai-penggerak-ekonomiumat.html. 